\title{
DROGA POLITYKI SPOŁECZNEJ W KATOLICYZMIE OBSZARU JEZZYKA NIEMIECKIEGO Przyczynek do teorii i praktyki katolickiej nauki spolecznej
}

Tak zwana „rewolucja przemysłowa”, a przede wszystkim jej niepożądane następstwa, oznaczone terminem „kwestia społeczna”, nadały rozwojowi społeczno-gospodarczemu XIX stulecia określone piętno. W walce o uporanie się $\mathrm{z}$ tymi nowego rodzaju problemami doszło na obszarze języka niemieckiego do utworzenia katolickiego ruchu społecznego. W trwających dziesiątki lat konfrontacjach ze stanowym konserwatyzmem, z liberaliznem (kapitalizmem) i ze socjalizmem (marksizmem) wystąpiły powoli zarysy samodzielnego rozwiązania kwestii społecznej: chodziło teraz nie o przywrócenie do życia minionego starego porządku, lecz o pozytywne ustosunkowanie się do nowego rozwoju; nie o panowanie kapitału, lecz o gospodarkę w służbie człowieka; nie o walkę klasową ani rewolucję, lecz o partnerstwo i integrację robotników w społeczeństwie. Ze zmienną intensywnością i w różnych konkretyzacjach powyższe linie przewodnie określały katolicki ruch społeczny także w XX stuleciu, w okresie weimarskim i aż do chwili obecnej.

Następujące uwagi nie chcą i nie mogą dać żadnego całościowego obrazu katolickiego ruchu społecznego w Niemczech i jego drogi w ostatnich 150 latach. Uwagi te wydobywają jedynie niektóre punkty widzenia, które w większym czy mniejszym stopniu tę drogę określały. Oto one:

1. Starania o „c z ęśc i ow ą” politykę społeczną, tzn. o pozytywne ustosunkowanie się do utrzymującego się porządku gospodarczego, przy jednoczesnym usunięciu jego wypaczeń;

2. Ujrzenie konieczności państwowej interwencji w dziedzinie gospodarczej i społecznej;

* Artykuł F. J. Stegmanna, profesora katolickiej nauki społecznej na Uniwersytecie w Bochum, jest przekładem referatu wygłoszonego w maju $1984 \mathrm{r}$. w PAT w Krakowie. Por. tegoż auitora: Von der Sozialreform zur Gesellschaftspolitik. Wege der katholisch-sozialen Bewegung, w serii: Kirche und Gesellschaft $\mathrm{Nr} 100, \mathrm{He}-$ rausgegeben von der Katholischen Sozialwissenschaftlichen Zentralstelle Mönchengladbach. Przekład fragmentów encyklik papieskich pochodzi z tekstów ogłoszonych w 332-B34. zelszycie ,Znaku” (19183). 
3. Samopomoc pra cobior ców przez zrzeszanie się i zorganizowane zastępstwo interesów;

4. Idea partnerstwa s połe c z nego, która opiera się na wzajemnej zależności względnie przyporządkowaniu pracy i kapitału i stara się także pracobiorców wciągnąc świadomie we współdecyzję i we współodpowiedzialność.

\section{I. „CZESSIOWA” POLITYKA SPOÆECZNA W RAMACH UTRZYMUJĄCEGO SIĘ PORZĄDKU GOSPODARCZEGO}

Jedno z najtrudniejszych pytań, przed którym stał w XIX wieku katolicki ruch społeczny, brzmiało: Czy rozwiązanie problemów społecznych winno nastąpić przez całkowicie nowe ukształtowanie istniejącego porządku, a więc przez reformę społeczną - przy czym za tło służyły mniej lub więcej stanowe wyobrażenia według średniowiecznego wzoru - czy też tylko przez usunięcie, wypaczeń wewnątrz istniejącego systemu gospodarczego, a więc na drodze polityki soc jalnej, względnie społecznej?

Katolicki ruch społeczny rozpoczyna się $w$ latach pięćdziesiątych i sześćdziesiątych XIX stulecia. Wcześniej jedynie nieliczni głębiej widzący obserwatorzy swoich czasów wskazywali na nadciągającą problematykę społeczną. Oni i przeważająca większość niemieckiego katolicyzmu główną przyczynę kwestii społecznej dostrzegali w ogóle w zani$\mathrm{ku}$ starych stanowych członów społeczeństwa. Z tej racji złe sytuacje społeczne wydawały się im do przezwyciężenia jedynie przez nową budowę społeczeństwa jakoś stanowo ukształtowaną. Typowym przejawem tej postawy był chyba Franciszek von Baader najwybitniejszy przedstawiciel romantycznej krytyki społecznej, (w sposób miarodajny wywarła ona wpływ na katolicki ruch społeczny), jak również czasopismo „Historisch-politischen Blätter", które od połowy stulecia aż do założenia Rzeszy w r. 1871 było czołowym periodykiem w katolicyzmie społecznym ${ }^{1}$.

Postanowienie kwestii: całościowa (stanowa) reforma społeczna czy raczej polityka społeczna wewnątrz trwającego systemu gospodarczego, sprawiło, że mniej więcej od końca lat sześćdziesiątych zaczęła dokony-

1 Por. F. von Ba a der, Ubber das dermalige Mißverhältnis der Vermögenslosen oder Proletairs zu den Vermögen besitzenden Klassen der Sozietät in betreff ihres Auskommens, sowohl in materieller als in intelektueller Hinsicht, aus dem Standpunkt des Rechts betrachtet (1835), [w:] Texte zur katholischen Soziallehre. Bd. 2: Dokumente zur Geschichte des Verhältnisses von Kirche und Arbeiterschaft am Beispiel der KAB. Hrsg. vom Bundes verband der Katholischen Arbeitnehmer-Bewegung (KAB) Deutschlands, Kevelaer 1976, s. 43-53. Na temat „Historisch-politischen Blättern" por.: F. J. S te g mann, Von der ständischen Sozialreform zur staatlichen Sozialpolitik. Der Beitrag der „Historisch-politischen Blätter” zur Lösung der sozialen Frage, München-Wien 1965. 
wać się w katolicyzmie społecznym głęboka przemiana. Myśl o przezwyciężeniu istniejącego systemu gospodarczego poczęła coraz bardziej ustępować na plan dalszy i została zastąpiona przez wołanie o państwowe prawo pracy i ustawodawstwo socjalne, które miało usunąc jedynie wypaczenia tego systemu. Otóż najwyraźniej ujawniła się ta nowa orientacja u mogunckiego biskupa Wilhelma Emmanuela von Kettelera, który był najwybitniejszą postacią $\mathrm{w}$ katolicyzmie społecznym XIX wieku. Jeśli w pierwszym okresie swojego działania - pozostając pod nienajmniejszym wpływem stanowych wyobrażeń - należał on do najbardziej zdecydowanych przeciwników liberalizmu gospodarczego, to w r. 1869, w mowie do robotników katolickich, przyznał całkiem otwarcie po raz pierwszy, że można ,bezwarunkową wolność we wszystkich dziedzinach gospodarki społecznej” uważać za konieczną i „zbawienną” 2. Jego referat na temat polityki socjalnej, wygłoszony $w$ tym samym roku na konferencji biskupów we Fuldzie, nie żądał już zastąpienia kapitalistycznego systemu gospodarczego przez inny, lecz głosił, że trzeba ,,go złagodzić, że należy szukać odpowiednich lekarstw dla jego wszystkich poszczególnych złych następstw, a również robotnikom winno się dozwolić, by mieli udział w tym, co jest dobre w systemie, w jego błogosławieństwach" " Jaśniej chyba nie dałoby się sformułować tej przemiany, jaka nastąpiła od stanowej, wszystko obejmującej reformy socjalnej, reprezentowanej dotąd przez Kettelera i większość katolicyzmu społecznego, do częściowej polityki socjalnej w istniejącym porządku gospodarczym. Tą afirmacją istniejącego porządku Ketteler wskazał katolicyzmowi społecznemu nowy kierunek.

Encyklika Leona XIII Rerum novarum z r. 1891 przyjęła to rozstrzygnięcie, podjęte już w katolicyzmie społecznym Niemiec na korzyść częściowej polityki społecznej, i usiłowała przede wszystkim w jasnym świetle postawić wzajemne stosunki między przedsiębiorcami i robotnikami w ramach istniejącego porządku gospodarczego. Najpierw przeciwstawił się papież koncepcji, że walka klasowa przedstawia nieobalalne prawo historii, ponieważ między pracą a kapitałem istnieje nieprzekraczalne przeciwienstwo. Obydwa te czynniki - przy wszystkich słusznych sprzecznych interesach - są o wiele bardziej nawzajem do siebie przyporządkowane i powinny współdziałać, ,,jak poszczególne członki w ciele ludzkim” współdziałają; albowiem ,,jedna drugiej bezwzględnie potrzebuje i ani kapitał bez pracy, ani bez kapitału praca istnieć nie może" (15).

${ }^{2}$ W. E. von Ketteler, Die Arbeiterbewegung und ihr Streben im Verhältnis zu Religion und Sittlichkeit, [w:] Texte zur katholischen Soziellehre. Bd. 2, jw. s. 243, (por. s. 241-262).

${ }^{3}$ Tenże, Sozialcaritative Fürsorge der Kirche für die Arbeiterschaft, tamże, s. 231 (por. s. $225-240$ ). 
Następnie upomniał papież robotników, by wypełniali obowiązki wynikające z dobrowolnie i sprawiedliwie zawartej umowy o pracę, oraz pracodawców, by zatrudnionych u siebie pracowników traktowali po ludzku i nie wykorzystywali ich jak jakąś maszynę (por. 16 n., 34). W ten sposób również Leon XIII wskazywał drogę polityki społecznej w kwestii: czy totalna reforma istniejącego systemu społecznego, czy też częściowa polityka wewnątrz tego porządku.

Najsilniejszym motorem postulowanych przez papieża dążeń polityki społecznej stało się założone w r. 1890 stowarzyszenie ludowe Volksverein für das katholische Deutschland ${ }^{4}$. Rozwinęło się ono szybko w masową organizację katolicko-społeczną i w r. 1900 liczyło około 187 tys. członków, dziesięć lat później 652 tys. a w r. 1914 ponad 800 tys. członków. Cały kraj został pokryty siecią sekretariatów, które udzielały członkom porad $\mathrm{w}$ sprawach pracy oraz $\mathrm{w}$ kwestiach podatkowych i socjalno-politycznych. Wielu przewodniczących ruchu katolicko-społecznego zdobywało na kursach szkoleniowych stowarzyszenia cały arsenał środków pomocnych w ich pracy politycznej i związkowej. Celem wszystkich wysiłków było poinformowanie szerokich warstw ludowych o nowych problemach wynikających $\mathrm{z}$ rozwoju społecznego, jak również wciągnięcie ich do praktycznej współpracy przy rozwiązywaniu tych problemów. W ten sposób Volksverein potwierdził istniejący porządek gospodarczy, żądał jednak usunięcia jego wypaczen. W sumie prowadził on społeczną, ekonomiczną i polityczną pracę oświatową, która wtenczas była jedyną w swoim rodzaju, a i później takiej pracy w katolicyzmie niemieckim nigdy już nie było.

W stawianiu zadań polityce społecznej dla usunięcia wypaczeń istniejącego porządku gospodarczego najbardziej wyróżnił się Franciszek Hitze. W dwa lata po święceniach kapłańskich i studiach w Rzymie Hitze został w r. 1880 sekretarzem generalnym stowarzyszenia Arbeiterwohl, założonego przez społecznie nastawionych katolickich przedsiębiorców; począwszy od 1893 piastował w Münster pierwszą i przez długi czas jedyną w Niemczech katedrę uniwersytecką ,chrześcijańskiej nauki społecznej", dziesiątki lat był rzecznikiem w sprawach polityki społecznej partii Centrum w Reichstagu i bez przesady winien być wyróżniony jako czołowa postać $\mathrm{w}$ społecznym katolicyzmie niemieckim po śmierci Kettelera w r. 1877 aż do okresu weimarskiego. W młodości zaangażował się on na rzecz „reorganizacji stanów” i „, socjalizmu stanowego” ${ }^{\circ}$. Gdy jednak potem jako sekretarz generalny stowarzyszenia Arbeiterwohl i zde--

4 Por. H. Heitzer, Der Volksverein für das katholische Deutschland im Kaiserreich 1890-1914, Mainz 1979.

5 F. Hitze, Kapital und Arbeit und die Reorganisation der Gesellschaft, Paderborn 1880 , s. III n., VI n. 
klarowany polityk społeczny Reichstagu stanął na gruncie codziennych spraw polityki społecznej, dochodził coraz bardziej do przekonania, że poszczególne pociągnięcia $\mathrm{w}$ ramach istniejącego porządku prędzej rozwiążą problemy socjalne niż jakaś choćby najlepiej pomyślana reorganizacja społeczeństwa. Głównym zadaniem powinno być ,stałe podnoszenie" udziału robotników $\mathrm{w}$,,postępie gospodarczym przez oględne kontynuowanie ustawodawstwa w zakresie ochrony pracy i ubezpieczeń" ". Na tym gruncie działało Centrum oraz Hitze, jako jego rzecznik w sprawach polityki społecznej i jako jej motor w Reichstagu.

\section{ZADANIE PAŃSTWOWEJ POLITYKI GOSPODARCZEJ I SPOEECZNEJ}

Jak alternatywa: ,wszechstronna (stanowa) reforma społeczna, czy częściowa polityka społeczna", tak równie ważna była dla dziewiętnastowiecznego katolicyzmu społecznego kwestia: czy rozwiązywanie społecznych problemów jest także zadaniem państwa, czy tylko sprawą pojedynczych i wolnych sił społecznych? W pierwszej mowie społeczno-politycznej, wygłoszonej w jednym z niemieckim parlamentów, Franciszek Józef Ritter von Buss, jedna z najbardziej charakterystycznych postaci w początkach katolicyzmu społecznego, już w r. 1837 w badeńskim Landtagu, po dokonaniu bystrej analizy kwestii społecznej, przedłożył obszerny projekt środków zaradczych ze strony państwa w dziedzinie polityki gospodarczej i społecznej: stworzenie zdrowej równowagi między rolnictwem, rzemiosłem i przemysłem, lepsze wykształcenie robotników, a przede wszystkim stosunkowo daleko idące ustawy w zakresie ochrony pracy; przedsiębiorcy winni być zobowiązani do wynagradzania robotników $\mathrm{w}$ gotówce, a nie $\mathrm{w}$ produktach fabrycznych, i przestrzegać kwartalny termin wypowiedzenia. Czas pracy dorosłych winien trwać najwyżej 14 godzin. Wreszcie budynki fabryczne powinny być stale nadzorowane przez urzędy zdrowia. Jeżeli Buss także później położył nacisk na społeczne wysiłki Kościoła, to przecież on jako pierwszy wskazał drogę do nowoczesnej polityki socjalnej państwa i tym samym wyprzedził to, co dopiero $\mathrm{z}$ trudem trzeba było zdobywać w drugiej połowie stulecia ${ }^{7}$.

Aż do lat sześćdziesiątych włącznie kwestia społeczna w niemieckim katolicyzmie była jednak uważana za problem w pierwszym rzędzie religijny i charytatywny, a jej rozwiązania oczekiwano jedynie w działal-

${ }^{6}$ Tenże, Arbeiterfrage, [w:] Staatslexikon. Bd. 1, Freiburg 1901, s. 263 (por. s. $253-288)$.

7 F. J. Bu B, Uber die mit dem fabrikmäßigen Gewerbsbetrieb verbundenen Nachteile und die Mittel ihrer Verhütung, [w:] Texte zur katholischen Soziellehre. Bd. 2, jw. s. $54-86$. 
ności pastoralnej i charytatywnej Kościoła, a nie państwa. Młody Wilhelm Emmanuel von Ketteler na pierwszym zjeździe katolików (Katholikentag) w r. 1848 w Moguncji może najlepiej wyraził powszechną opinię, gdy podkreślił, że jedynie „Kościołowi katolickiemu jest zastrzeżone ostateczne rozwiązanie kwestii społecznej; państwo natomiast, jakiekolwiek by chciało wydać zarządzenia, nie posiada żadnej mocy ku temu" ".

$\mathrm{W}$ połowie lat sześćdziesiątych zaczęła zarysowywać się zmiana w poglądach Kettelera, który od r. 1850 był biskupem Moguncji. W swojej wspomnianej już mowie przed robotnikami katolickimi zażądał on $\mathrm{w} r$. 1869 m.i. skrócenia czasu pracy, zachowania spoczynku niedzielnego, jak też zakazu pracy fabrycznej dla dzieci $\mathrm{w}$ wieku szkolnym, dla dorastających dziewcząt i dla matek ${ }^{9}$. Również w wymienionym już socjalno-politycznym orzeczeniu $\mathrm{z}$ tego samego roku, przedstawionym konferencji biskupów w Fuldzie, zażądał on całego szeregu państwowych zarządzeń dla ochrony pracy, jak: zakazu względnie ograniczenia pracy dzieci, zamknięcia miejsc pracy szkodliwych dla zdrowia, pomocy państwowej dla niezdolnych do pracy, ale przede wszystkim ,kontroli państwa nad wypełnieniem ustawodawstwa pracy przez mianowanie oficjalnych inspektorów fabrycznych" ${ }^{10}$. Ketteler uważał więc przezwyciężenie nędzy społecznej za zadanie, które również państwu powinno być postawione i w ten sposób ukazał katolicyzmowi społecznemu nowy kierunek.

To żądanie, „,by wreszcie na drodze ustawodawczej rozpocząc rozwiązywanie kwestii społecznej" 11, zostało z naciskiem podjęte przez zrzeszenia chrześcijańsko-społeczne, które począwszy od lat sześćdziesiątych powstawały wszędzie w okręgu przemysłowym reńsko-festfalskim i o których jeszcze będzie mowa. Również doroczne zjazdy katolików (Katholikentage) przyłączyły swe głosy do wołania o interwencję państwa, a w siedemdziesiątych i osiemdziesiątych latach wciąż na nowo żądały ,pomocy państwa i jego ustawodawstwa” w celu usunięcia istniejącej nędzy ${ }^{12}$.

Do pierwszego wyraźnego osiągnięcia w dziedzinie politycznej doprowadziła ta ewolucja wówczas, gdy partia Centrum wniosła do Reichstagu w r. 1877 „Wniosek Galena”. Centrum powstało jako partia w r. 1870 i stanowiło polityczne przedstawicielstwo katolickiej części ludności. Centrum od początku nie chciało stanowić jakiejś „,katolickiej” partii, a tylko być partią środka. Gdy w grudniu 1870 r. spotkali się

8 Verhandlungen der ersten Versammlung des katholischen Vereins Deutschlands zu Mainz, Mainz 1848, s. 52.

9 W. E. von Ketteler, Die Arbeiterbewegung, s. 249-258.

10 Tenże, Sozialcaritative Fürsorge, s. 236.

11 „Christlich-soziale Blätter” 4 (1871) s. 54.

12 Verhandlungen der XXIII. Generalversammlung der katholischen Vereine Deutschlands zu Breslau 1872, Breslau 1872, s. 277. 
posłowie sprzyjający założeniu partii, odrzucili oni określenie „Frakcja katolicka", które to określenie również było przedmiotem debaty, i wybrali nazwę „Centrum” (Partia środka) ${ }^{13}$. Także później usiłowano uwolnić się od zarzutu, że są tylko partią katolicką; w rzeczywistości jednak Centrum pozostało ograniczone do katolickiej części ludności. „Wniosek Galena" proponował więc, obok ograniczenia wolności zarobkowania dla ochrony rzemiosła i popierania związków korporatywnych, całą gamę szczegółowych zarządzeń państwowych społeczno-politycznych. W następnym okresie głównymi żądaniami Centrum w dziedzinie polityki społecznej pozostało państwowe ustawodawstwo dla ochrony pracy (ograniczenie pracy kobiet i dzieci, ustalenie maksymalnego czasu dniówki roboczej, przestrzeganie odpoczynku niedzielnego, rozbudowa inspekcji fabryk).

Oficjalne „tak” kościelnego urzędu nauczycielskiego dla państwowej polityki gospodarczej i społecznej wypowiedział w r. 1891 Leon XIII w encyklice Rerum novarum. Papież wyszedł z ogólnego twierdzenia, że państwo ma obowiązek zabezpieczać dobrobyt ogółu i jednostki. Czyniąc to, państwo „może się stać pożyteczne innym klasom, może też w wysokim stopniu polepszyć warunki życia proletariatu, a to na podstawie najlepszego swego prawa i bez ściągania na siebie oskarżeń o wdzieranie się w prawa cudze; właśnie bowiem troska o dobro ogólu stanowi obowiązek państwa” (26). Przeto „kiedy pracodawcy obarczają pracowników nadmiernymi ciężarami lub kiedy im narzucają inne, niegodne człowieka warunki, kiedy się zdrowiu szkodzi przez pracę nad siły lub zmusza do pracy niestosownej dla wieku lub płci, w tych wypadkach należy się [...] uciec do siły i powagi praw państwowych" (29). Tym samym encyklika w gorąco dysputowanej kwestii, dotyczącej publicznego lub prywatnego rozwiązywania problemów społecznych, wyraźnie przyznała rację kierunkowi interwencjonistycznemu i wezwała również państwo do rozwiązywania kwestii społecznej; postawiła przed państwem zadania, które z czasem stały się oczywiste i dla nas są dzisiaj oczywiste, jednak przez długi czas takimi wcale nie były.

To ,tak” dla istniejącego porządku gospodarczego, połączone z równoczesnymi staraniami, aby państwową polityką społeczną usunąć nadużycia i wypaczenia, określiło także dyskusję nad kapitalizmem, toczącą się w okresie weimarskim w katolicyzmie społecznym. Niemiecki katolicyzm społeczny w przeważającej swojej większości uważał za nieodzowną gospodarkę rynkową, wolną konkurencję i umiarkowane dą-

13 Por. K. Buchheim, Geschichte der christlichen Parteien in Deutschland, München 1953, s. 206; Der sozialpolitische Antrag des Grafen Galen im Reichstag vom 19. März 1877, [w:] Deutsche Parteiprogramme. Hrsg. von Wilhelm Mom ms e n, München-Wien 1964, s. 227 n. 
żenie do zysku. Odrzucone zostało indywidualistyczne wynaturzenie, „,nieograniczona dominacja własności kapitału” ${ }^{14}$. Oswald von Nell-Breuning, ten niepodejrzewany o sympatie dla liberalizmu gospodarczego stary mistrz katolickiej nauki społecznej, stwierdził w r. 1929: „Ustrój gospodarczy, nastawiony na pomnożenie kapitału, sam ze siebie nie jest niegodziwy ani zły". Konieczne dla funkcjonowania gospodarki dążenie do zysku musi być jednak utrzymane w pewnych granicach przez władzę publiczną: „A więc pow śc i ą g a ć dążenie do zysku przez oddziaływanie państwa, ale nie zas tęp ow a ć przez biurokrację" ${ }^{15}$.

Podobnie w r. 1931 oceniła encyklika Quadragesimo anno ten sposób gospodarowania, w którym ,do wspólnej działalności gospodarczej jedni wnoszą kapitał, a inni pracę" (100), tak samo kontrakt o płacę ,sam z siebie nie zasługuje na potępienie". Encyklika odrzuciła jednak kapitalistyczne społeczeństwo klasowe, w którym ,kapitał w tym celu i na takich warunkach wynajmuje robotników, czyli proletariat do pracy, że przemysł i całe życie gospodarcze uzależnia wyłącznie od siebie i na swoją wyłącznie korzyść obraca, nie uwzględniając ludzkiej godności robotników, społecznego charakteru gospodarstwa, sprawiedliwości społecznej i dobra ogółu” (101).

Temu wynaturzeniu miała przeszkodzić względnie usunąc je z jednej strony samopomoc, szczególnie przez łączenie się robotników w związki zawodowe, o czym jeszcze będzie mowa, z drugiej jednak państwowa polityka spoleczna. W katolicyzmie okresu weimarskiego jej motorem był polityk socjalny i kapłan Henryk Brauns, przed wojną światową czołowy współpracownik Związku Ludowego (Volksverein), a od r. 1920 minister Rzeszy $\mathrm{w}$ resorcie pracy ${ }^{16}$. Brauns starał się przede wszystkim o budowę i rozbudowę prawa pracy, jak też o kontynuowanie ustawodawstwa ubezpieczeń socjalnych. Ustawa o powszechnej mocy wiążącej umów zbiorowych z r. 1923, zastąpienie w r. 1924 poprzedniej, zupełnie nie wystarczającej opieki nad ubogimi (Armenpflege) przez nowoczesne prawo opieki społecznej (Fürsorgerecht), oraz ustawa o pośrednictwie pracy i o ubezpieczeniu od bezrobocia z r. 1927 - wszystko to były najważniejsze ustawy, na które Brauns po ośmioletnim urzędowaniu mógł w r. 1928 spojrzeć jako na swoje dzieło.

To, co do końca okresu weimarskiego zostało wypracowane w katolicyzmie społecznym, nadało kierunek tym wyobrażeniom, które po r. 1945 pod hasłem ,społeczna gospodarka rynkowa” wycisnęły znamię

14 H. Pes c h, Lehrbuch der Nationalökonomie, Bd. 2, Freiburg 1925, s. 227.

$15 \mathrm{O}$. von Nel1-Breuning, Kirche und Kapitalismus, M. Gladbach o. J. 1929 , s. 7.

${ }_{16}$ Por. H. Mockenhaupt, Weg und Wirken des geistlichen Sozialpolitikers Heinrich Brauns, Paderborn 1977. 
na rozwoju Republiki Federalnej: „tak” dla ustroju własności prywatnej i dla wolnej konkurencji, ale w połączeniu z ciężarami społecznymi. Nie na ostatnim miejscu potwierdza to katolicka dyskusja w sprawie społecznej gospodarki rynkowej w latach piećdziesiątych i sześćdziesiątych.

Pod społeczną gospodarką rynkową rozumieją jej (neoliberalni) zwolennicy zagwarantowaną przez państwo wolną konkurencję pod względem produktywności wraz z wytyczonymi celami społecznymi: przyporządkowanie gospodarki popytowi, sprawiedliwy podział dochodu według wydajności, wyrównanie niepożądanych skutków przez państwową politykę socjalną i ułatwienie koniecznych strukturalnych przemian gospodarczych przez ,interwencje przystosowujące do rynku" ${ }^{17}$. To zwrócenie się katolików niemieckich ku społecznej gospodarce rynkowej nastąpiło $\mathrm{w}$ latach piećdziesiątych przede wszystkim w praktycznej polityce gospodarczej i społecznej dzięki CDU/CSU, jako politycznemu przedstawicielstwu ich większości. $\mathrm{Na}$ arenie pozapolitycznej, szczególnie w katolicyzmie społecznym, zwrot ten wyraził się mniej silnie.

Głównymi argumentami zwolenników społecznej gospodarki rynkowej było to, że zabezpieczenie wolności ma nadrzędne znaczenie zarówno dla neoliberalizmu, jak i dla katolicyzmu społecznego, że zasada pomocniczości wymaga zdecentralizowanego ustroju gospodarki rynkowej, że społeczna gospodarka rynkowa nie jest już żadnym liberalizmem manczesterskim, lecz stoi w służbie człowieka, zawiera „system odniesienia do czynnika społecznego" ${ }^{18}$, a przede wszystkim odznacza się wielką wydajnością produkcyjną.

Krytycy społecznej gospodarki rynkowej wystąpili szczególnie przeciwko przeakcentowywaniu walki konkurencyjnej, automatyzmu rynkowego i zarazem gospodarczego oraz wolności indywidualnej. Wprawdzie potwierdzali oni również wolną gospodarkę wymienną i konkurencyjną, żądali jednak włączenia jej we wszechstronną politykę społeczną. Zadanie państwa polega nie tylko na tym, żeby w sensie formalnym zabezpieczyć walkę konkurencyjną wraz z wolnością gospodarczą; jego zadaniem jest raczej zagwarantowanie ,realizacji dobra społecznego oraz społecznego wyniku gospodarowania" ${ }^{19}$. Do „,dobra społecznego" należy np. przygotowanie wystarczającej ilości miejsc pracy, humanizacja świata pracy i współdecydowanie pracobiorców także w kwestiach gospodar-

17 Zwięzłe ujęcie tego zagadnienia daje: A. M üller-Armack, Soziale Marktwirtschaft, [w:] Handbuch der Sozialwissenschaft, Bd. 9, Stuttgart-Tübingen-Göttingen 1956, s. 390-392. Por. również: F. J. S t e g m a n n, Die katholische Kirche in der Sozialgeschichte. Die Gegenwart, München-Wien 1983, s. 9-28.

18 Goetz Briefs, Katholische Soziallehre, Laissez-Faire-Liberalismus und Soziale Marktwirtschaft, [w:] Was wichtiger ist als Wirtschaft?, Ludwigsburg 1960? s. 41 (por. s. 33-44).

19 F. Kl ù ber, Neoliberale und soziale Marktwirtschaft, „Die neue Ordnung” 14 (1960) s. 329 (por. s. $321-334$ ).

33 - Analecta Cracoviensia 
czych; do „społecznego wyniku” natomiast należy sprawiedliwy podział dochodu i sprawiedliwy ustrój własności - by wymienić tylko niektóre centralne przykłady. Katolicki ruch robotniczy przyjął w szczególny sposób te żądania jako własne ${ }^{20}$.

$\mathrm{Społeczna} \mathrm{gospodarka} \mathrm{rynkowa} \mathrm{-} \mathrm{tak} \mathrm{jak} \mathrm{ją} \mathrm{rozumie} \mathrm{katolicka}$ nauka społeczna - opowiada się za wolną konkurencją i wysoką wydajnością gospodarki, ale jednocześnie za odczekaniem przy regulowaniu nieznośnych sytuacji społecznych, żeby je w późniejszym czasie skorygować; s połeczna gospodarka rynkowa wymaga raczej, aby ukierunkowanie ku temu, co społeczne i co ludzkie zostało z góry i w zrównoważony sposób wciągnięte $\mathrm{w}$ politykę gospodarczą, żeby polityka gospodarcza była uprawiana jako część wszechstronnej polityki społecznej, a to w tym celu, by przez to osiągnąc dobro społeczne i społeczny rezultat gospodarki.

III. SAMOPOMOC ROBOTNIKÓW PRZEZ ZRZESZANIE SIĘ I ZORGANIZOWANE ZASTĘPSTWO INTERESOW

W XIX w. prawo robotników do samopomocy przez zrzeszanie się i zorganizowane zastępstwo interesów było podobnie zakwestionowane, jak pozytywne nastawienie do interwencji państwa. Ustawa socjalistyczna Bismarcka (Sozialistengesetz), która pozostawała w mocy od 1878 do 1890 r., miała rozbić powstające od lat sześćdziesiątych organizacje pracobiorców, co też się jej w dużej mierze udało dokonać. Pełnomocnik Centralnego Związku Niemieckich Przemysłowców (Centralverband Deutscher Industrieller) oświadczył w r. 1890, że przemysłowcy nigdy nie będą pertraktować „na równej stopie” ${ }^{21}$ z przedstawicielami jakiejś organizacji robotniczej.

Tymczasem przedstawiciele katolicyzmu społecznego okazali się znowu tymi, którzy bardzo wcześnie zaangażowali się na rzecz prawa robotników do zrzeszania się. Romantyczny krytyk społeczny Baader już w r. 1835 przyznał im prawo do „łączenia się" (,sich assozieren”) 22; Buss w 1851 polecił tworzenie ,wolnych związków górników” (,freien Gewerksvereinen") ${ }^{23}$. Pierwsze katolickie związki robotników powstały w połowie stulecia (Regensburg 1849) prawie równolegle do związków czelad-

${ }_{20}$ Por. Gesellschaftspolitische Grundsatzerklärung der KAB vom 23. März 1964 (odpowiedź na krytykę wyjaśnienia społeczno-politycznych zasad).

${ }_{21}$ H. A. Bue ck, Arbeitseinstellung und Fortbildung des Arbeitsvertrages, [w:] Verhandlungen der 1890 in Frankfurt abgehaltenen Generalversammlung des Vereins für Socialpolitik, Leipzig 1890, s. 150 (por. s. 131-154).

$22 \mathrm{~F}$. von B a a der, jw. s. 47.

23 F. J. Buß, Die Aufgabe des katholischen Theils teutscher Nation in der Gegenwart oder der katholische Verein Teutschlands, Regensburg 1851, s. 94. 
ników, które Adolf Kolping zakładał począwszy od końca lat czterdziestych. W następstwie liberalizacji górnictwa powstały w latach piećdziesiątych w okręgu Ruhry katolickie związki górników. Katolicki ruch robotniczy otrzymał mocne impulsy od biskupa Kettelera. W cytowanej wyżej mowie z r. 1869 bez zastrzeżeń uznał on wysiłki zmierzające do „organizowania robotników, w celu nadania wspólnymi siłami ważności ich interesom i prawom” za „usprawiedliwione i zbawienne, a nawet za konieczne, jeżeli robotnik nie ma być całkowicie zmiażdżony przez potęgę zcentralizowanego pieniądza" ${ }^{24}$; potwierdził też prawo do strajku. W r. 1877 widział on ,,w związkach zawodowych [...] drogę [...] po której można by dążyć do założenia powszechnej organizacji" ${ }^{25}$. Począwszy od lat sześćdziesiątych wszędzie $\mathrm{w}$ reńsko-westfalskim okręgu przemysłowym były zakładane „chrześcijańsko-socjalne” związki wykraczające poza środowiska robotnicze. W r. 1870 liczyły one ok. 200 tys. członków ${ }^{26}$. Gdy „,walka o kulturę” (Kulturkampf) i ustawa socjalistyczna Bismarcka zgotowały gwałtowny koniec również większości chrześcijańsko-społecznych związków, organizacja Arbeiterwohl, a przede wszystkim jej generalny sekretarz Hitze podjęli w latach osiemdziesiątych starania o tworzenie związków robotniczych (Arbeitervereine) w parafiach. W r. 1889 sprawozdanie podało liczbę 232 zw'ązków z 52 tys. członków ${ }^{27}$. Po zniesieniu ,zakazu socjalistycznego" na początku lat dziewięćdziesiątych powstały pierwsze lokalne chrześcijańskie „związki górnicze” (Gewerkvereine).

W tej sytuacji ukazała się w r. 1891 encyklika Rerum novarum. Najpierw wezwała ona ogólnie także robotników do zrzeszania się. Przy tym prawu do zrzeszania się przyznał papież wprost rangę prawa naturalnego: „Wolność bowiem tworzenia prywatnych stowarzyszeń ma człowiek na podstawie prawa natury, a państwo istnieje nie dla niszczenia prawa natury, ale dla jego ochrony; dlatego państwo zakazując prywatnych związków obywateli, podważałoby własne podstawy, skoro tak samo ono [...] z jednego pochodzi źródła, ze społecznej natury ludzkiej" (38). Tym razem papież Leon XIII zajął wyraźne stanowisko jako obrońca prawa robtników do zrzeszania się, czyniąc to w czasie, kiedy w Niemczech policja jeszcze prześladowała takie związki. Zapobieganie strajkom przez wczesne usuwanie ich przyczyn encyklika nazwała wprawdzie

${ }^{24}$ W. E. von Ketteler, Die Arbeiterbewegung, s. 244.

25 Tenże, Kann ein katholischer Arbeiter Mitglied der sozialistischen Arbeiterpartei sein?, [w:] Texte zur katholischen Soziallehre. Bd. 2, jw. s. 282 (por. s. 274-286). s. 74 .

${ }_{26}$ Por. H. Budde, Christentum und soziale Bewegung, Aschaffenburg 1962,

${ }^{27}$ Statistik der katholischen Arbeitervereine sowie der Vereine für weibliche und jugendliche Arbeiter, „Arbeiterwohl" 9 (1899) s. 147-158. 
„,szczególnie skuteczną i zdrową" rzeczą, tym samym jednak uznawała ona strajk za zasadniczo ostateczny środek w konflikcie społecznym (por. 31). W kwestii własnych chrześcijańskich związków zawodowych (Gewerkschaften) encyklika uczyniła uwagę, że gdy inne organizacje szkodzą dobru ogółu i „opanowawszy wszystkie warsztaty pracy, na karę nędzy skazują tych robotników, którzy się do nich nie chcą przyłączyć", wtenczas robotnicy chrześcijańscy winni ,zakładać nowe stowarzyszenia, [...] by się wydobyć z tej niesprawiedliwej i nieznośnej niewoli" (40).

Począwszy od przełomu XIX i XX wieku nad młodymi chrześcijańskimi związkami zawodowymi ${ }^{28}$, które $\mathrm{w}$ dziewięćdziesiątych latach nabrały wielkiego rozpędu, zaciążyły niestety kontrowersje znane w historii jako „Gewerkschaftsstreit”. Chodziło zasadniczo o pytanie, czy katoliccy robotnicy mogą się jednoczyć w międzywyznaniowych chrześcijańskich związkach zawodowych, czy tylko w wydziałach zawodowych ( $\mathrm{Fa}$ chabteilunge) we wnątrz katolickich związków robotniczych (Arbeitervereine), istniejących na terenie parafii lub diecezji. Wprawdzie w końcu wzięły górę chrześcijańskie związki zawodowe, to jednak spory trwały aż do pierwszej wojny światowej i wyrządziły katolickiemu ruchowi społecznemu szkody trudne do naprawienia. Spór ten nabrał ostrości światopoglądowej w pewnej mierze stąd, że na zapleczu był podtrzymywany przez walkę między modernizmem i integralizmem, a walka ta w ogóle poruszyła umysły w europejskim katolicyzmie.

Prawno-konstytucyjne uznanie związków zawodowych w Niemczech po raz pierwszy zostało wyrażone przez konstytucję weimarską. Podczas gdy przedtem związki zawodowe były zaledwie mniej lub więcej tolerowane, teraz art. 159 zagwarantował „,wolność zrzeszania się dla ochrony i ulepszania warunków pracy i gospodarowania dla każdego i dla wszystkich zawodów".

IV. IDEA PARTNERSTWA SPOEECZNEGO. WSPÓEDECYZJA PRACOBIORCÓW

Z samopomocą robotników przez zrzeszanie się i przez organizowane przedstawicielstwo interesów ściśle związana jest idea partnerstwa społecznego, która spoczywa na wzajemnym uzależnieniu względnie przyporządkowaniu kapitału i pracy i usiłuje także pracobiorców wciągnąc do decydowania i odpowiedzialności, tzn. do współdecydowania. W Republice Federalnej współdecydowanie należy dotąd do najbardziej spornych problemów gospodarczych i społeczno-gospodarczych. Dyskusja zaś bywa tutaj prowadzona w ten sposób, jakoby starania o współdecydowa1982.

${ }_{28}$ Zob. M. Schneider, Die Christlichen Gewerkschaften 1894-1933, Bonn 
nie były oznaką wyłącznie powojennego rozwoju sprawy. Historia społeczna i gospodarcza ostatnich 150 lat pokazuje jednak, że problematyka współdecydowania jest zasadniczo tak stara, jak samo uprzemysłowienie, i że niemiecki katolicyzm społeczny wniósł zasadniczy wkład w dotychczasową dyskusję.

Wielokrotnie już wspomniany romantyczny krytyk społeczny Baader przedstawił $w$ r. 1835 roszczenia $\mathrm{p} \mathrm{rawne} \mathrm{robotników} \mathrm{do} \mathrm{reprezenta-}$ cji w zgromadzeniach stanowych w postaci „,rzeczników przez siebie wybranych" ${ }^{29}$. Począwszy od lat pięćdziesiątych XIX w. w dyskusjach społeczno-politycznych coraz więcej miejsca zajmowała idea spółdzielczości. Po stronie katolickiej przede wszystkim bp Ketteler zabiegał o urządzanie produkcyjnych zrzeszeń (Produktivassoziationen), jak je dawniej nazywano. Jeżeli widział on w nich głównie drogę do udziału robotników w zyskach przedsiębiorstwa, to również mówi on $\mathrm{w}$ swoich propozycjach bardzo wyraźnie o ,uczestniczeniu" robotnika jako ,,przedsiębiorcy” w bieżących sprawach zakładu (am Geschäftsbetrieb) ${ }^{30}$, a tym samym także moment zabierania głosu, współdecydowania. Te wysiłki, za którymi stoi wiele akcji podobnego rodzaju, ukazują, że prawo robotników do zabierania głosu (Mitspracherecht) i problem porząd$\mathrm{ku}$ obejmującego przedsiębiorców i robotników powstały razem z industrializacją gospodarki i dyskutowane były przede wszystkim w katolicyzmie społecznym.

Historyczny przebieg spraw pokazuje następnie, że polepszenie prawnej pozycji robtników, rozpoznanie ich interesów wobec przedsiębiorców przez swoich wybranych przedstawicieli, jak również ich współdziałanie przy regulowaniu spraw zakładowych i ponadzakładowych stanowiły, począwszy od lat osiemdziesiątych, centralne punkty programowe coraz silniejszego ruchu katolicko-społecznego w przeciwstawieniu do wielu innych potężnych grup społeczeństwa. W ten sposób Hitze, jako sekretarz stowarzyszenia Arbeiterwohl, oraz przemysłowiec katolicki Franciszek Brandts byli jednymi z pierwszych, którzy w latach osiemdziesiątych w tekstylnym przedsiębiorstwie Brandtsa w Mönchengladbach wprowadzili tzw. komisje robotnicze (Arbeiterausschüsse) - odpowiedniki dzisiejszych rad zakładowych. Miały one zapewnić załodze , udział w zarządzaniu" ${ }^{31}$. To głównie z inicjatywy Hitzego przed pierwszą wojną światową frakcja Centrum w Reichstagu raz po raz, chociaż daremnie,

29 F. von B a a de r, s. 49.

30 Texte zur katholischen Soziallehre. Bd. 2, jw. s. 202.

31 M. Sering, Arbeiter-Ausschüsse in der deutschen Industrie. Gutachten, Berichte, Statuten, Leipzig 1890, s. 2. Na ten temat por. także: F. J. S t e g m a n n, Der soziale Katholizismus und die Mitbestimmung in Deutschland, Paderborn 1978, s. $76-131$. 
wnosiła projekt ustawy o zakładowych przedstawicielstwach robotniczych.

W społecznym katolicyzmie okresu weimarskiego odstąpiono wreszcie od domagania się społecznego współdecydowania na korzyść żądania współdecydowania gospodarczego. Przedstawiciele katolickiego ruchu społecznego - przede wszystkim zaś Henryk Brauns jako przewodniczący społeczno-gospodarczej komisji Zgromadzenia Narodowego współdziałali w sposób zdecydowany ze sobą, by doprowadzić do uchwalenia w r. 1920 art. 165 konstytucji weimarskiej oraz ustawy o radach zakładowych. Art. 165 zawierał ogólną zasadę podstawową o równouprawnionym współdziałaniu robotników przy rozwoju gospodarczym i w tym celu przewidział urządzenie systemu rad gospodarczych wraz $\mathrm{z}$ radą gospodarczą Rzeszy na czele, przy odpowiednim udziale robotników. Ustawa o radach zakładowych zapewniała pełne współdecydowanie w sprawach społecznych i personalnych, jak również podejmowanie współdecyzji gospodarczej w fazie wstępnej, ponieważ rada zakładowa mogła po raz pierwszy oddelegować jednego lub dwóch członków do rady nadzorczej przedsiębiorstwa.

Maciej Erzberger, pochodzący z katolickiego ruchu społecznego południowo-zachodnich Niemiec, zaproponował w r. 1921, gdy pełnił funkcję ministra finansów Rzeszy, utworzenie spółdzielni fabrycznych (Werksgenossenschaften) przez daną załogę przedsiębiorstwa. Udział w zyskach i odpowiednie powiększenie kapitału miało sprawić, że blisko $50 \%$ kapitału zakładowego przechodziło $\mathrm{w}$ posiadanie załogi. Tym samym koncepcja ta, jako pierwszy model przedsiębiorstwa w katolicyzmie społecznym - w oparciu o współwłasność - przewidywała parytetowe uczestniczenie robotników ,w zarządzaniu przedsiębiorstwem" ${ }^{22}$. Bernard Letterhaus, sekretarz katolickiego ruchu społecznego na zachodzie Niemiec, zażądał w końcu na kongresie Katolickiej Międzynarodówki Robotników (Kolonia 1928) przyznania robotnikom w zakładzie pracy i w całej gospodarce pełnego ,,prawa współdecydowania i współkształtowania" ${ }^{33}$. Letterhaus należał do antyhitlerowskiego ruchu oporu i stał się ofiarą egzekucji po zamachu z 20 lipca 1944 r. Jeśli nawet wszystkie te dążenia $\mathrm{w}$ ciągu prawie jednego stulecia nie występowały pod hasłem współdecydowania (Mitbestimmung) - hasło to wynurzyło się dopiero w okresie weimarskim - to jednak pokazują one, że jego treść jest tak stara, jak sama industrializacja i że katolicyzm społeczny wniósł istotny wkład w ówczesne dyskusje.

32 M. Erzberger, Christlicher Solidarismus als Weltprinzip, M. Gladbach 1921 , s. 26.

${ }_{33}$ B. Letterhaus, Die Wertung des Lohnarbeiters in der heutigen Wirtschafts- und Gesellschaftsordnung, im Lichte der katholischen Weltanschauung, [w:] Texte zur katholischen Soziallehre, Bd. 2, jw. s. 1059 (por. s. 1042-1073). 
Zaraz po r. 1945 wznowiono dyskusję nad współdecydowaniem. W okresie przygotowawczym do kongresu katolików w Bochum w r. 1949 koloński kardynał Frings wskazał na ,wysoką stosowność współdziałania i współdecydowania" ${ }^{34}$. Na samym kongresie kwestia współdecydowania odegrała bardzo ważną rolę. Po intensywnych dyskusjach delegaci zgodzili się na następującą rezolucję: „,Robotnicy i przedsiębiorcy katoliccy są zgodni w tym, że prawo współdecydowania wszystkich współpracujących w odniesieniu do spraw społecznych, personalnych i gospodarczych jest prawem naturalnym w porządku zamierzonym przez Boga i w prawie tym zawiera się współodpowiedzialność. Domagamy się jego ustawowego określenia" ${ }^{35}$. To prawno-naturalne uzasadnienie znane jako ,bochumski nieszczęśliwy wypadek przy pracy” - zostało oczywiście wycofane w wyniku późniejszych sporów, w których wziął udział również ówczesny papież Pius XII.

Górnicze prawo o współdecydowaniu z r. 1951, jak również ustawa o strukturze zakładu z r. 1952 wyciszyły debatę na ten temat w Republice Federalnej. Górnicze prawo o współdecydowaniu (obejmujące zarówno górnictwo, jak i przemysł żelazno-stalowy) w spółkach kapitałowych, zatrudniających więcej niż 1000 pracobiorców, wymaga parytetowego obsadzenia rady nadzorczej przez przedstawicieli współwłaścicieli kapitału i pracobiorców (plus dodatkowo jeden neutralny członek) a w kierownictwie przedsiębiorstwa wymaga jednego dyrektora pracy, który winien otrzymać zgodę pracobiorców. Ustawa zaś o strukturze zakładu (Betriebsverfassungsgesetz) dla pozostałej części gospodarki przewidziała współdecydowanie $\mathrm{w}$ sprawach społecznych i personalnych jak również jedną trzecią miejsc w radzie nadzorczej dla pracobiorców. Ustawa ta została w r. 1976 uzupełniona inną, określającą również parytetowe obsadzenie rady nadzorczej w spółkach kapitałowych, zatrudniających (z reguły) więcej niż 2000 pracobiorców. W razie zaistnienia impasu rozstrzygającą decyzję podejmuje przewodniczący, ustanowiony przez przedstawicieli kapitału. Przy końcu lat pięćdziesiątych dyskusja znowu się ożywiła. Powodem tego było $\mathrm{m}$. in. to, że przesunięcie się niektórych punktów ciężkości przedsiębiorstw poza przemysł górniczy zaczęło ograniczać parytetowe współdecydowanie.

W tej sytuacji ukazała się w r. 1961 encyklika Mater et magistra, niewątpliwie sprzyjająca idei współdecydowania. Papież Jan XXIII oświadczył, ,że pracownicy domagają się słusznie należytego im udziału w życiu przedsiębiorstwa wytwórczego, w którym są zatrudnieni" (91)

${ }^{34} \mathrm{~J}$. Kard. Frings (Hersg.), Verantwortung und Mitverantwortung in der Wirtschaft, Köln 1949, s. 123.

${ }_{35}$ Gerechtigkeit schafft Frieden. Der 73. Deutsche Katholikentag in Bochum, Padeborn 1949, s. 114. 
i że ,istniejąca dziś w różnych przedsiębiorstwach wytwórczych tendencja do powierzania najbardziej odpowiedzialnych obowiązków pracownikom jest całkowicie zgodna [...] z naturą ludzką" (93). Podłożem tej wypowiedzi było przodujące miejsce, przyznane pracy przez papieża: „W samej bowiem naturze człowieka jest zakorzenione wymaganie, by ten, kto w działalność wytwórczą wnosi wkład swej pracy, miał również prawo uczestniczenia w zarządzaniu przedsiębiorstwem" (82). Albowiem praca, ,jako bezpośredni wynik działania ludzkiej osoby, musi być stawiana wyżej, niż zasoby dóbr materialnych, które z samej ich istoty należy traktować jako nadrzędne" (107).

Z kolei Sobór Watykański II podjął myśl encykliki Mater et magistra. Konstytucja duszpasterska Gaudium et spes wskazuje najpierw na nadrzędne znaczenie pracy: „Praca ludzka, która polega na tworzeniu i wymianie nowych dóbr lub na świad.czeniu usług gospodarczych, góruje nad innymi elementami życia gospodarczego, ponieważ te mają jedynie charakter narzędzi. Praca bowiem [...] pochodzi od osoby" (67). Po tej zasadniczej wypowiedzi o pracy zwraca się konstytucja duszpasterska do sprawy współdecydowania: „W przedsiębiorstwach gospodarczych stowarzyszają się dla pracy osoby, czyli ludzie wolni i pełnoprawni, stworzeni na obraz Boży. W związku z tym, uwzględniając zadania każdego, mianowicie: właścicieli, najemców, dyrektorów, robotników, a równocześnie nie naruszając koniecznej jedności w kierowaniu całością, należy popierać, odpowiednio obmyślanymi sposobami, czynny udział wszystkich w pieczy nad przedsiębiorstwem" (68).

Również najnowsza encyklika Laborem exercens z r. 1981 nie zajmuje tu innej pozycji. Laborem exercens, podobnie jak konstytucja duszpasterska Gaudium et spes i encyklika Mater et magistra, podkreśla ogólną etyczno-społeczną zasadę, a mianowicie ,zasadę pierwszeństwa pracy przed kapitałem" $(12,1)$. Papież Jan Paweł II podbudowuje tę zasadę potrójnym argumentem: po pierwsze, praca jest zawsze praca człowieka, któremu przysługuje ,prymat [...] wobec rzeczy” $(12,6)$; po wtóre, dobra tej ziemi ,nie mogą służyć człowiekowi inaczej, jak tylko poprzez pracę" $(12,2)$; wreszcie „,kapitał jako zespół środków produkcji” $(12,1)$, sam ,,jest owocem [...] pracy człowieka" $(12,4)$. Wśród konkretnych form urzeczywistnienia tej etyczno-społecznej zasady, obok udziału w zyskach, współwłasności itp., wymienia encyklika również udział ,pracowników w zarządzaniu", a więc współdecydowaniu $(14,5)$.

Chociaż tekst encykliki Mater et magistra i sformułowania konstytucji Gaudium et spes zostały zinterpretowane w sposób zróżnicowany ${ }^{36}$, to jednak następujące punkty są jednoznaczne: (1) Sobór widzi przedsię-

${ }^{36}$ Por. F. J. Steg ma n n, Die katholische Kirche, s. 93-111. 
biorstwo nie wyłącznie jako techniczno-gospodarczy aparat dla wytwarzania dóbr, lecz przede wszystkim jako związek ludzi. Zatem właściciel przedsiębiorstwa nie ma prawa stawiac pracobiorce wraz $\mathrm{z}$ aparatem środków produkcji na tym samym poziomie, oceniać go jedynie jako czynnik po stronie kosztów. (2) Kadra kierownicza (Management), właściciele or a z robotnicy przyczyniają się łącznie do osiągnięć przedsiębiorstwa. Wszyscy oni winni, odpowiednio do sprawowanej funkcji i bez uszczerbku dla jednolitości kierowania przedsiębiorstwem, mieć swój udział w procesie jego kształtowania. (3) W jaki sposób ten dział ma być urzeczywistniony, w jakich formach i w jakim wymiarze o tym Sobór nie rozstrzyga. Potwierdza zasadę, potwierdza tę dziedzinę partnerstwa społecznego - nic więcej. Tym samym pytanie o konkretne kształtowanie współdecydowania zostaje odesłane do rzeczoznawców, do fachowców, pracobiorców, właścicieli, przedsiębiorców i naukowców.

W czterech centralnych dziedzinach problemowych (starania o ,częściową" politykę społeczną, konieczność interwencji państwa, samopomoc pracobiorców i partnerstwo społeczne - współdecydowanie) usiłowałem naszkicować socjalno-polityczną, względnie społeczno-polityczną drogę w katolicyzmie obszaru języka niemieckiego. Niektóre sprawy nie zostały ujęte tematycznie, jak np. niewystarczające dotąd wysiłki o szersze rozmieszczenie majątku produkcyjnego. Naszkicowana droga katolickiego ruchu społecznego była określana przez różne czynniki i w swoich szczegółach nie jest $\mathrm{z}$ pewnością wzorcem powszechnie uznanym ani podręcznikiem recept. Droga ta pokazuje jednak, że jedn a sprawa - przy wszystkich rozczarowaniach - zawsze była silnie podkreślana i stanowiła cel: idea partnerstwa socjalnego (Sozialpartnerschaft). Również w państwie i w gospodarce zawsze chodzi o ludzi, rozumiejących siebie jako partnerów i pragnących się spotkać. 